Wilfrid Laurier University

Scholars Commons @ Laurier

Biology Faculty Publications

Biology

2004

\title{
A Re-Examination of the Taxonomic Boundaries of Symphysia (Ericaceae)
}

Sam. P. vander Kloet

Acadia University

Jennifer L. Baltzer

Wilfrid Laurier University, jbaltzer@wlu.ca

Julia H. Appleby

University of Toronto

Rodger C. Evans

Acadia University

Donald T. Stewart

Acadia University

Follow this and additional works at: https://scholars.wlu.ca/biol_faculty

\section{Recommended Citation}

vander Kloet, Sam. P.; Baltzer, Jennifer L.; Appleby, Julia H.; Evans, Rodger C.; and Stewart, Donald T., "A Re-Examination of the Taxonomic Boundaries of Symphysia (Ericaceae)" (2004). Biology Faculty Publications. 13.

https://scholars.wlu.ca/biol_faculty/13

This Article is brought to you for free and open access by the Biology at Scholars Commons @ Laurier. It has been accepted for inclusion in Biology Faculty Publications by an authorized administrator of Scholars Commons @ Laurier. For more information, please contact scholarscommons@wlu.ca. 


\title{
A re-examination of the taxonomic boundaries of Symphysia (Ericaceae)
}

\author{
Sam P. vander Kloet ${ }^{1}$, Jennifer L. Baltzer ${ }^{1,2}$, Julia H. Appleby ${ }^{1,3}$, Rodger C. Evans ${ }^{1}$ \& Donald T. \\ Stewart ${ }^{1}$ \\ IDepartment of Biology, Acadia University, Wolfville, Nova Scotia, B4P 2R6, Canada. sam.vanderkloet@aca- \\ diau.ca (author for correspondence); jenniferbaltzer@utoronto.ca; julie.appleby@utoronto.ca; rodger. \\ evans@acadiau.ca; don.stewart@acadiau.ca \\ 2 Current Address: Faculty of Forestry, University of Toronto, Toronto, Ontario, M5S 3B3, Canada \\ ${ }^{3}$ Current Address: Department of Molecular and Medical Genetics, University of Toronto, Toronto. Ontario, \\ MSS 1A8, Canada
}

\begin{abstract}
DNA sequence data were generated for the nuclear ITS region for Symphysia racemosa and for 26 additional Vaccinieae representing 12 sections in the genus Vaccinium plus one species from each of five additional segregate genera. Our focus is on the placement of $S$. racemosa relative to Vaccinium sensu stricto and Vaccinium sect. Oreades (represented by $V$. poasanum). Maximum parsimony analysis of $608 \mathrm{bp}$ of nrlTS region suggests that $S$. racemosa and $V$. poasanum form a well-supported clade in spite of substantial morphological divergence. Furthermore, this clade is a sister group to a clade consisting of all segregate genera examined. These molecular results led us to undertake a morphological cladistic analysis of all of the other Central American green-flowered taxa. We suggest that the genus Symphysia should be expanded to encompass these 15 taxa, despite the lack of phylogenetic resolution within this group. This will necessitate eight new combinations, viz., Symphysia almedae $(=V$. almedae $)$, Symphysia costaricensis $(=V$. costaricense $)$, Symphysia jefensis $(=V$. jefense), Symphysia orosiensis (=V. orosiense), Symphysia ovata (= Lateropora ovata), Symphysia perardua (=V. santafeënsis), Symphysia poasana (=Vaccinium poasanum), Symphysia santafeënsis (= L. santafeënsis), and Symphysia tubulifera (= L. tubulifera).
\end{abstract}

KEYWORDS: Ericaceae, ITS, molecular phylogenetics, Symphysia, taxonomy, Vaccinium

\section{INTRODUCTION}

Symphysia racemosa (Vahl) Stearn was first recognised as a genus distinct from Vaccinium by Smith (1935). He cited a number of unique morphological features that defined this monotypic taxon including pleiomerous flowers, short carnose corollas, squat anthers, and anther tubules that dehisce by terminal pores (Fig. 1). Sleumer (1941) concurred with this segregation and noted that Symphysia flowers contain 10-14 stamens as well as a thick pedicel attached to a salver-shaped calyx tube.

In contrast to the above treatment, Stevens (1971) suggested that Symphysia "is no more different from Vaccinium sensu stricto than is Vaccinium $\S$ [sect.] Oreades Sleumer" and similarly, Luteyn \& Wilbur (1978) argued that transferring Symphysia to Vaccinium "would not expand the limits of this extremely diverse genus". In the most recent review of the genus, vander Kloet (1985) concluded that adding Symphysia to Vaccinium is tantamount "to making the genus a dumping ground for taxa of uncertain affinity in the Vaccinieae..."

In this paper, we demonstrate that sequence data from the nuclear encoded ITS region clearly unites $S$. racemosa and $V$. poasanum. Given this result, we also undertook a morphological maximum parsimony analysis of 15 additional Central American green-flowered taxa to investigate their relationship to these two species.

\section{MATERIALS AND METHODS}

Molecular analysis. - Representative taxa were selected to include $S$. racemosa, Vaccinium poasanum sect. Oreades Sleumer, 20 other species of Vaccinium s.str. representing 11 sections, and five additional segregate genera in Ericaceae (Table 1). Sequences for two ericad outgroup taxa, Kalmia cuneata Michx. (U45905) and Rhododendron alabamense Rehder (AF091941) were obtained from the GenBank database.

Plant DNA was extracted from fresh eophylls and dried leaves from herbarium specimens using the DNeasy extraction kit (Qiagen). The manufacturer's extraction protocol was followed without modification. The nrITS region was PCR-amplified using the universal primers ITS-4 and ITS-5P of Möller \& Cronk (1997). The PCR reaction conditions were as follows: initial 
Table 1. Ericad nrlTS sequences analysed. Voucher specimens corresponding to these sequences are deposited in the E.C. Smith Herbarium, Acadia University (ACAD). VDK = vander Kloet.

\begin{tabular}{|c|c|c|c|}
\hline Genus, section, and species & Provenance & Ref. number & Genbank number \\
\hline \multicolumn{4}{|l|}{ Segregate genera } \\
\hline Cavendishia grandifolia Hoer. & Ecuador & 8023 & AY274558 \\
\hline Ceratostema peruviana Gmel. & Peru & 5657 & AY274559 \\
\hline Disterigma rimbachii (A.C. Smith) Luteyn & Ecuador & 8011 & AY274556 \\
\hline Macleania rupestris (H.B.K.) A.C. Smith & Costa Rica & VDK 513686 & AY 274557 \\
\hline Sphyrospermum buxifolium Poepp. \& Endl. & Trinidad & VDK X123490 & AY274555 \\
\hline Symphysia racemosa (Vahl) Stearn & Martinique & VDK 227274 & AY27455 \\
\hline \multicolumn{4}{|l|}{ Vaccinium sect. Oreades } \\
\hline Vaccinium poasanum & Costa Rica & VDK 1313686 & AY274560 \\
\hline \multicolumn{4}{|l|}{ V. sect. Batodendron } \\
\hline Vaccinium arboretum & Florida & VDK 49190 & AY274569 \\
\hline \multicolumn{4}{|l|}{$V$ sect. Bracteata } \\
\hline Vaccinium acrobactracteatum & Papua-New Guinea & VDK 86875 & AY 274562 \\
\hline Vaccinium barandamum & Luzon & VDK 181092 & AY274563 \\
\hline Vaccinium horizontale & Papua-New Guinea & VDK 530775 & AY274561 \\
\hline Vaccinium varingiaefolium & Java & HS 84-3 & AY274564 \\
\hline \multicolumn{4}{|l|}{ V. sect. Conchophyllum } \\
\hline Vaccinium nummularia & Nepal & VDK 1261092 & AY 274576 \\
\hline \multicolumn{4}{|l|}{$V$ sect. Cyanococcus } \\
\hline Vaccinium corymbosum & Florida & VDK ABS-5,6,7 & AY 274570 \\
\hline Vaccinium darrowii & Florida & VDK ABS8 & AY274573 \\
\hline Vaccinium myrsinites & Georgia & VDK 422574 & AY 274572 \\
\hline Vaccinium tenellum & Georgia & VDK 133686 & AY274571 \\
\hline \multicolumn{4}{|l|}{$V$ sect. Eococcus } \\
\hline Vaccinium fragile & Yunnan & VDK 12896 & AY 274580 \\
\hline \multicolumn{4}{|l|}{ V. sect. Galeopetalum } \\
\hline Vaccinium gaultherifolium & Vietnam & VDK 1231197 & AY 274577 \\
\hline \multicolumn{4}{|l|}{$V$. sect. Hemimyrtillus } \\
\hline Vaccinium cylindraceum & Azores & VDK 1271097 & AY274574 \\
\hline \multicolumn{4}{|l|}{$V$. sect. Herpothamnus } \\
\hline Vaccinium crassifolium & North Carolina & VDK 431881 & AY274579 \\
\hline \multicolumn{4}{|l|}{ V. sect. Macropelma } \\
\hline Vaccinium reticulatum & Hawaii & VDK 31390 & AY 274578 \\
\hline \multicolumn{4}{|l|}{ V. sect. Pyxothamnus } \\
\hline Vaccinium consanguineum & Costa Rica & VDK 714686 & AY274566 \\
\hline Vaccinium floribundum & Ecuador & Ballington 14036 (ACAD) & AY 274567 \\
\hline Vaccinium meridionale & Jamaica & VDK $10 X I I 85$ & AY274565 \\
\hline Vaccinium ovatum & British Columbia & VDK 231879 & AY274568 \\
\hline \multicolumn{4}{|l|}{$V$. sect. Vaccinium } \\
\hline Vaccinium uliginosum & New Hampshire & VDK 220895 & AY274575 \\
\hline \multicolumn{4}{|l|}{ Outgroup: } \\
\hline Kalmia cuneata & & & U48603 \\
\hline Rhododendron alabamense & & & AF072478 \\
\hline
\end{tabular}

denaturation $\left(95^{\circ} \mathrm{C}, 2 \mathrm{~min}\right)$, followed by 35 cycles of denaturation $\left(95^{\circ} \mathrm{C}, 45 \mathrm{~s}\right)$, annealing $\left(46^{\circ} \mathrm{C}, 45 \mathrm{~s}\right)$ and extension $\left(72^{\circ} \mathrm{C}, 1 \mathrm{~min} 15 \mathrm{~s}\right)$, and concluding with a final extension $\left(72^{\circ} \mathrm{C}, 4 \mathrm{~min}\right)$. PCR reactions were performed in $25 \mu \mathrm{l}$ volumes containing $10 \times$ Amp buffer, $25 \mathrm{mM}$ $\mathrm{MgCl}_{2}, 10 \mathrm{mM}$ of each deoxynucleotide triphosphate, 1 $\mu \mathrm{l}$ of template DNA, $10 \mathrm{mg} / \mathrm{ml}$ bovine serum albumin and $5 \mathrm{U}$ Taq polymerase.

A band corresponding to approximately 700 bp was excised from a $2 \%$ agarose gel in $1 \times$ TAE buffer and purified using a gel extraction kit (Qiagen). PCR prod-

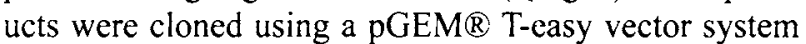
(Promega). A total of $500 \mathrm{ng}$ of purified plasmid DNA was then sequenced in both directions on an Applied Biosystems 377 sequencer (University of Maine DNA sequencing facility). All sequences were submitted to GenBank.

Alignment of approximately $600 \mathrm{bp}$ of sequence for the 29 Ericaceae sequences was performed using ClustalW (Thompson \& al., 1994). Sites with gaps were 

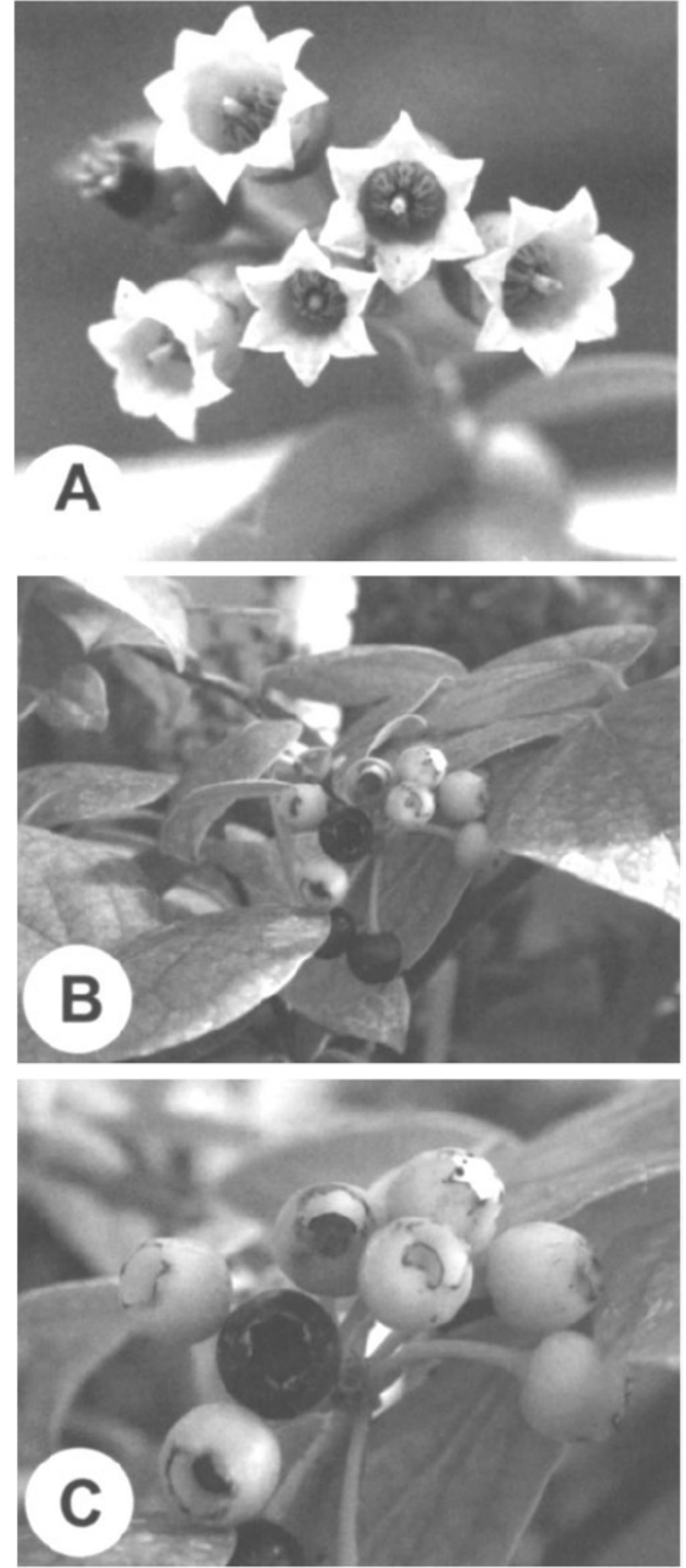

Fig. 1. Floral and fruit characteristics of Symphysia racemosa (Vahl) Stearn.

either excluded from the analysis or alternatively were treated as a fifth character-state. Maximum parsimony analysis was conducted in PAUP* (Swofford, 2000) using a Branch and Bound search routine. Support for each node was determined using heuristic bootstrapping (1000 replicates, each with 10 random addition
Table 2. Characters used in the maximum parsimony analysis of Symphysia racemosa, Vaccinium poasanum, and various other green-flowered taxa listed by Luteyn \& Wilbur (1977).

\begin{tabular}{l} 
plesiomorphic - apomorphic \\
\hline 1. Lignotuber absent - present \\
2. Leaves conspicuously petiolate - subsessile \\
3. Leaf base attenuate to rounded - cordate and/or amplexicaul \\
4. Leaf venation pinnate - plinerved \\
5. Secondary \& tertiary veins neither strongly elevated nor \\
forming a pronounced reticulum on the blade - secondary \& \\
tertiary veins strongly elevated beneath forming a coarse \\
reticulum on the blade \\
6. Floral axis development complete prior to anthesis - the axis \\
continues to thicken until fruiting (i.e., becomes woody) \\
7. flowers 5 -merous - pleiomerous \\
8. calyx tube obscure at anthesis - well developed at anthesis \\
9. calyx tube terete at the base - lobed or angular at the base. \\
10. calyx tube glabrous - hirsute or pubescent and/or glandular. \\
11. calyx lobes obvious at anthesis - obscure (apiculate) at anthe- \\
sis \\
12. corolla lobes glabrous - floccose or glandular - hirsute on the \\
inside \\
13. corolla lobes much shorter than the tube ( $1: 4)$ - ca. as long as \\
the tube (1:1-1:3) \\
14. corolla tube glabrous - hirsute, pubescent or glandular \\
15. corolla not carnose (thin) - carnose and/or bistratose \\
16. base of anther spurless - spurred \\
17. anther sacs entire - split \\
18. anther tubules well developed - rudimentary or absent \\
19. anther tubule opening a pore - an introrse slit \\
\hline
\end{tabular}

sequences).

Morphological analysis. - Based on the results of the molecular analysis that grouped $V$. poasanum with $S$. racemosa (see below), we decided to examine relationships among a number of additional Caribbean and Central American green-flowered Vaccinieae of uncertain affinity using the protologues and examining the specimens cited by Luteyn \& Wilbur (1977), Wilbur \& Luteyn (1978) and Wilbur (unpubl.) at the New York Botanical Garden. A total of 19 morphological characters (Table 2) was examined. Character states were coded using representatives of Vaccinium s.str. (namely $V$. corymbosum L. and $V$. ovatum Pursh) as the outgroup (Table 3). Phylogenetic relationships among these taxa were reconstructed using a Branch and Bound search routine in PAUP* (Swofford, 2000).

\section{RESULTS AND DISCUSSION}

Results from the phylogenetic analysis of nrITS sequences clearly demonstrate a close relationship between Symphysia racemosa and Vaccinium poasanum (Fig. 2). Although the ITS sequence data are clearly not 
Table 3. Character states for the 19 morphological characters given in Table 2 coded with respect to the outgroup, represented by Vaccinium corymbosum and $V$. ovatum. New combinations and provenance of these taxa are provided in the text.

\begin{tabular}{llllllllllllllllllll}
\hline Species & $\mathbf{1}$ & $\mathbf{2}$ & $\mathbf{3}$ & $\mathbf{4}$ & $\mathbf{5}$ & $\mathbf{6}$ & $\mathbf{7}$ & $\mathbf{8}$ & $\mathbf{9}$ & $\mathbf{1 0}$ & $\mathbf{1 1}$ & $\mathbf{1 2}$ & $\mathbf{1 3}$ & $\mathbf{1 4}$ & $\mathbf{1 5}$ & $\mathbf{1 6}$ & $\mathbf{1 7}$ & $\mathbf{1 8}$ & $\mathbf{1 9}$ \\
\hline Lateropora ovata & 0 & 0 & 0 & 0 & 0 & 1 & 0 & 1 & 0 & 0 & 0 & 1 & 1 & 1 & 1 & 1 & 1 & 1 & 0 \\
Lateropora santafeënsis & 0 & 0 & 0 & 0 & 0 & 1 & 0 & 1 & 0 & 0 & 0 & 1 & 1 & 1 & 0 & 1 & 1 & 1 & 1 \\
Lateropora tubulifera & 0 & 0 & 0 & 0 & 0 & 1 & 0 & 1 & 1 & 0 & 1 & 1 & 1 & 1 & 0 & 1 & 1 & 1 & 1 \\
Vaccinium corymbosum & 0 & 0 & 0 & 0 & 0 & 0 & 0 & 0 & 0 & 0 & 0 & 0 & 0 & 0 & 0 & 0 & 0 & 0 & 0 \\
Vaccinium costaricense & 0 & 1 & 0 & 1 & 1 & 1 & 0 & 1 & 0 & 1 & 1 & 1 & 1 & 1 & 1 & 1 & 0 & 0 & 0 \\
Vaccinium jefense & 0 & 0 & 0 & 0 & 0 & 1 & 0 & 1 & 0 & 1 & 0 & 1 & 1 & 1 & 0 & 1 & 0 & 0 & 1 \\
Vaccinium orosiense & 0 & 1 & 1 & 1 & 0 & 1 & 0 & 1 & 0 & 0 & 1 & 1 & 0 & 1 & 0 & 1 & 0 & 0 & 0 \\
Vaccinium ovatum & 0 & 0 & 0 & 0 & 0 & 0 & 0 & 0 & 0 & 0 & 0 & 0 & 0 & 0 & 0 & 0 & 0 & 0 & 0 \\
Vaccinium poasanum & 0 & 0 & 0 & 0 & 0 & 1 & 0 & 0 & 0 & 0 & 1 & 0 & 0 & 0 & 0 & 1 & 0 & 0 & 0 \\
Vaccinium santafeënsis & 0 & 0 & 0 & 0 & 0 & 1 & 0 & 1 & 0 & 0 & 1 & 0 & 0 & 0 & 0 & 1 & 0 & 0 & 1 \\
Symphysia flocosum & 0 & 0 & 0 & 1 & 0 & 1 & 0 & 1 & 0 & 0 & 0 & 1 & 1 & 1 & 0 & 1 & 0 & 1 & 0 \\
Symphysia racemosa & 0 & 0 & 0 & 1 & 0 & 1 & 1 & 1 & 0 & 0 & 1 & 0 & 1 & 0 & 1 & 0 & 0 & 0 & 0 \\
species nov. I & 1 & 0 & 0 & 0 & 0 & 1 & 0 & 1 & 0 & 0 & 0 & 0 & 0 & 0 & 0 & 0 & 0 & 0 & 1 \\
species nov. II & 0 & 0 & 0 & 0 & 1 & 1 & 0 & 1 & 0 & 1 & 0 & 0 & 1 & 1 & 0 & 1 & 0 & 0 & 1 \\
species nov. III & 0 & 0 & 0 & 0 & 0 & 1 & 0 & 1 & 1 & 0 & 1 & 1 & 1 & 1 & 1 & 0 & 0 & 0 & 0 \\
species nov. IV & 0 & 0 & 0 & 0 & 0 & 1 & 0 & 1 & 0 & 1 & 0 & 1 & 1 & 1 & 1 & 0 & 0 & 0 & 0 \\
species nov. V & 0 & 0 & 0 & 1 & 0 & 1 & 0 & 0 & 0 & 0 & 1 & 0 & 1 & 0 & 0 & 0 & 0 & 0 & 0 \\
\hline
\end{tabular}

able to resolve relationships among many of the sections of Vaccinium represented here, $S$. racemosa and $V$. poasanum are united with 76 and $88 \%$ bootstrap support (with gaps treated as missing data or as an additional character state, respectively). When gaps are treated as a new character, there is considerable bootstrap support $(92 \%)$ for $S$. racemosa and $V$. poasanum grouping with the segregate genera. However, when these sites are eliminated from the analysis, support for this relationship drops to $54 \%$.

These phylogenetic patterns are corroborated by Kron \& al. (2002) and Kron (unpubl.), who not only found that $V$. poasanum and $V$. luteynii Wilbur are consistently linked with Symphysia, but also that this trilogy is a consistent subset within the Meso-American clade that comprises such South American segregate genera as Cavendishia Lindley, Macleania Hooker, Siphonandra Klotzsch and Psammisia Klotzsch. This Meso-American clade of segregate genera, which, according to Kron \& al (2002) has $93 \%$ bootstrap support, is linked to the Andean clade of segregates such as Satyria Klotzsch and Diogenesia Sleumer.

The taxonomic choices available are as follows. Either transfer all these segregate genera to Vaccinium or just transfer $V$. poasanum and $V$. luteynii to Symphysia. Before advocating the latter, we felt that taxa associated with this pair by Luteyn and Wilbur (1977), Wilbur \& Luteyn (1978) and Wilbur (unpubl.) and referred to as plants with "short, racemose, umbellate to subcorymbose inflorescences with green or yellowish corollas" ought to be examined. Furthermore, Lateropora A.C. Smith should be examined as it differs from these taxa only by two obvious characters: rudimentary antherial tubules and rupturing thecae.

Despite numerous attempts, we have not been able to successfully isolate and/or amplify DNA from the leaves of numerous herbarium specimens. Samples have historically been treated with alcohol and bromine to prevent rot that may render them useless for DNA analysis. Ideally, fresh ex situ, garden grown, or frozen material or possibly material stored in one of a number of field storage buffers (e.g., saturated $\mathrm{NaCl} / \mathrm{CTAB}$; see Štorchová \& al., 2000) should be used as a source of DNA. Furthermore, obtaining fresh flush from the field in the near future for these various green-flowered species is highly unlikely. Aside from $V$. poasanum and $S$. racemosa, all the taxa listed by Luteyn \& Wilbur (1977), Wilbur \& Luteyn (1978) and Wilbur (unpubl.) are rare local endemics. Indeed, eleven out of the fifteen taxa under consideration are only known from the type or type locality (see taxonomy below).

Given that molecular work was not feasible, we attempted a morphological maximum parsimony analysis for these taxa. Twelve equally parsimonious trees were generated (not shown). If we accept the $50 \%$ majority rule consensus tree (Fig. 3), then the Central American $V$. poasanum is an obvious outlier, but the Caribbean $S$. racemosa is linked with a group of species endemic to the Chiriqui Region of Panama and adjacent Costa Rica. Indeed, in all the morphological cladograms these two taxa are consistently separated but are in fact genetically very similar (only differing by $\sim 1 \%$ uncorrected sequence divergence). Note also that the only other species traditionally assigned to Symphysia (i.e., $S$. floccosa) is invariably placed in the same grade as the genus Lateropora. 


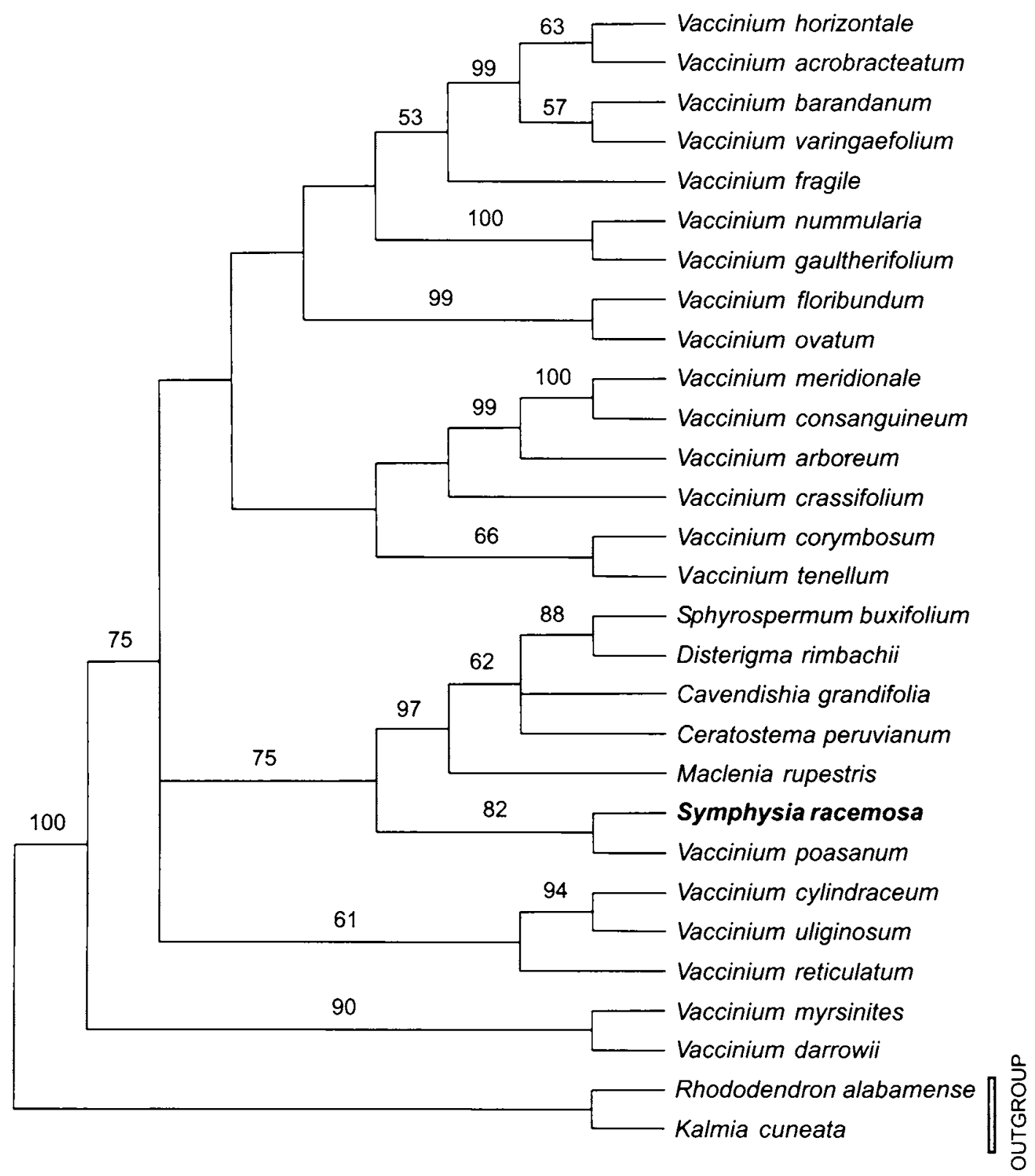

Fig. 2. Strict consensus Branch and Bound tree based on 608 bp of nrlTs sequence data for 21 Vaccinium species, Symphysia racemosa, and five additional segregate genera. Rhododendron alabamense and Kalmia cuneata were included as outgroup taxa. Branch and bound analyses yielded six trees of length 360 steps (retention index $=0.726$; consistency index $=0.617$, excluding autapomorphies). Numbers above the lines are bootstrap values obtained using a heuristic search.

These results, both molecular and morphological, suggest that $V$. poasanum is misplaced in Vaccinium and should be transferred to an expanded Symphysia defined by the following synapomorphies: (1) a short rachis that continues to thicken until fruiting, i.e., becomes woody; and (2) the pedicels continue to lengthen and thicken distally until fruiting. These flaring pedicels often bear a corona of 5-12 caducous pili around the margin of the cup, where it articulates with the calyx tube (see vander
Kloet, 1985, figs. $7 \&$ 9). Furthermore, flowers of this group have greenish-white to greenish-pink corollas often with floccose lobes, and stamens or parts thereof that are often reduced, may have short, squat filaments, an anther sac base which is often contracted into a spur, anther tubules that are often rudimentary or absent; and thecae that may rupture; the latter allowing for a novel way for pollen dispersal.

Although sizeable gaps remain in this cladogram and 


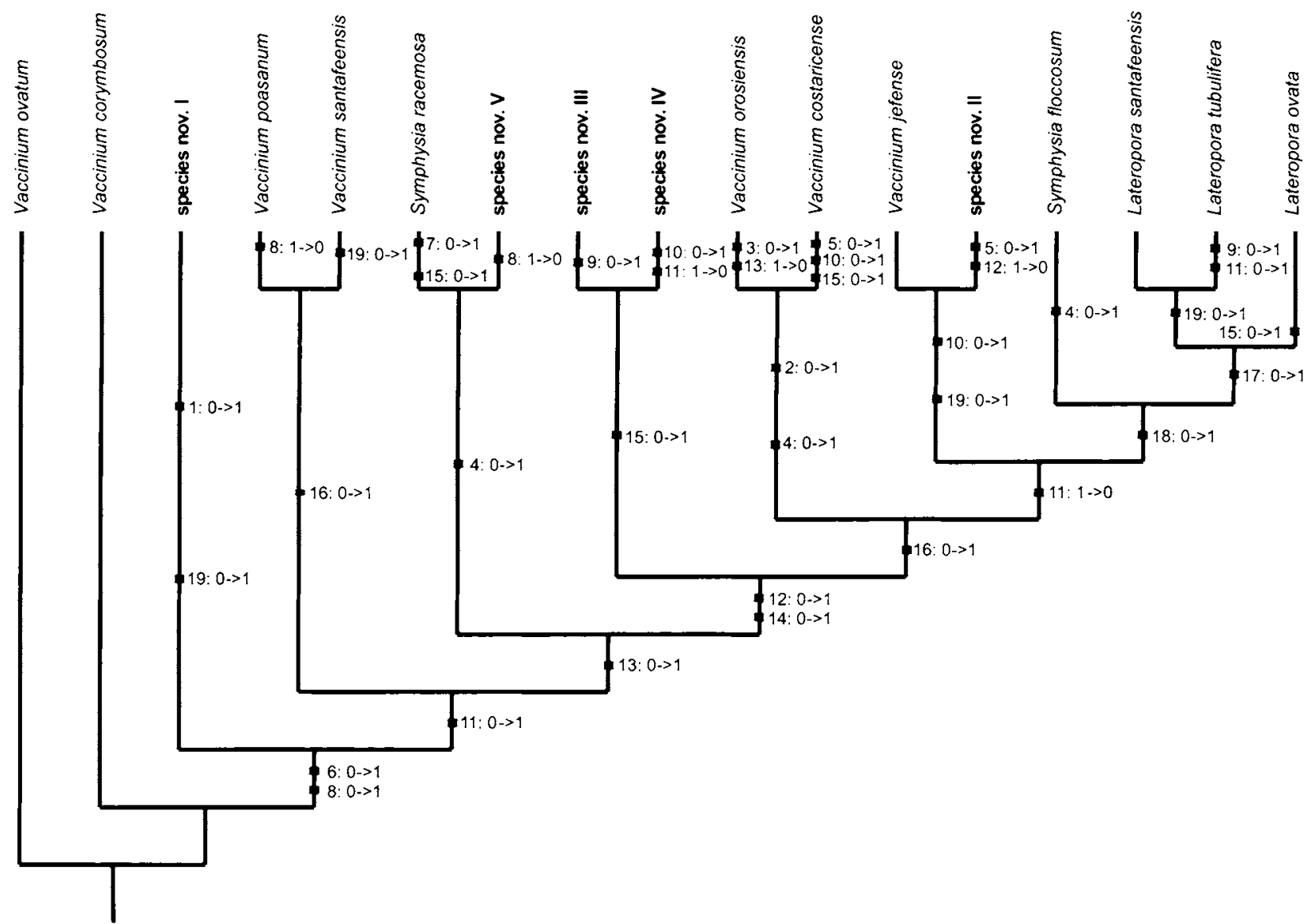

Fig. 3. One of 12 most parsimonious trees obtained from analysis of 19 morphological characters (see tables 2 and 3 for character state information). Branch and Bound analysis yielded trees of length 39 steps (retention index $=0.661$; consistency index $=0.444$, excluding autapomorphies).

others of the Vaccinia (see, for example, Kron \& al., 1999, and vander Kloet \& Patterson, 2000), revelation will come slowly as $90 \%$ of the 500 species in Vaccinium (Sleumer, 1941) are tropical or subtropical epiphytes, represented in the world's herbaria by only a few specimens.

\section{TAXONOMY}

Symphysia C.B. Presl, Epist. Symphysia (1827)

Type species: Hornemannia racemosa Vahl (1810) $\equiv$ Symphysia racemosa (Vahl) Stearn (1972).

Hornemannia Vahl in Skrivter Nat.-Selsk. Kiøben havnb: 120 (1810); non Hornemannia Willd. (1809)

Vaccinium § Oreades Sleumer, Bot. Jahrb. 71: 417 (1941)

Straggly to compact and erect, epiphytic or terrestrial shrubs. Leaves alternate, short petiolate, coriaceous, pinnately veined or plinerved. Inflorescence axillary or terminal, subfasciculate or racemose with many flowers on long pedicels. Flowers with the calyx tube articulate with the pedicel, calyx tube often expanding prior to anthesis, calyx lobes 5-7, often rudimentary; corolla usually campanulate, often sub-carnose, greenish white to greenish pink, 5-8 lobed, lobes often floccose; stamens $10-12$ (14) equal, usually $2 / 3$ the length of the corolla, the filaments \pm distinct, dorsally attached to the anthers near their midpoint, the anthers stout with granular thecae whose bases often end in a spur, the tubules rarely rudimentary but if present opening with a terminal pore or an introrse slit; style filiform and about as long as the corolla tubc; the ovary inferior. Fruit a white, pink, purple or black berry with numerous tiny seeds.

The genus Symphysia contains approximately 15 species in Central America and the Caribbean with its center of diversity in the Chiriqui Region of Panama and adjacent Costa Rica.

\section{Key to the species:}

1. Flowers pleiomerous; corollas bistratose and carnose

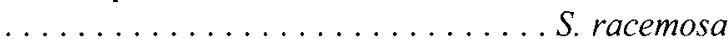
1. Flowers usually 5-merous; corollas subcarnose or 
thinner, not bistratose . . . . . . . . . . . . 2

2. Corollas $12-14 \mathrm{~mm}$ in diameter; tubules as long as or longer than the rest of the stamen......... 3

2. Corollas $<11 \mathrm{~mm}$ in diameter, tubules shorter than the rest of the stamen . . . . . . . . . . . 4

3. Calyx lobes ca. $0.5 \mathrm{~mm}$ long or less; calyx tube ca. 3 $\mathrm{mm}$ long at anthesis............. . poasana

3. Calyx lobes $3-4 \mathrm{~mm}$ long; calyx tube $5-7 \mathrm{~mm}$ long at anthesis . . ............. species nov. I [Based on material collected by J. L. Luteyn (NY) prior to 1990 . Protologues are to be written by R. L. Wilbur.]

4. Anther tubules absent or rudimentary; thecae usually split . . . . . . . . . . . . . . . . . 5

4. Anther tubules present, usually 1-4 mm long; thecae usually entire . . . . . . . . . . . . . 6

5. Petioles $>5 \mathrm{~mm}$ long; calyx lobes $4-5 \mathrm{~mm}$ wide ..

........................... ovata

5. Petioles $<5 \mathrm{~mm}$ long; calyx lobes ca. $2 \mathrm{~mm}$ wide . $\ldots \ldots \ldots \ldots \ldots \ldots$. . santefeënsis

6. Secondary and tertiary veins strongly elevated beneath forming a coarse reticulum on the blade. . 7

6. Secondary and tertiary veins neither strongly elevated nor forming a pronounced reticulum on the blade

........................... 8

7. Petioles 5-9 mm long; calyx lobes $5-6 \mathrm{~mm}$ long .. ...................... jefensis

7. Petioles $2-4 \mathrm{~mm}$ long; calyx lobes $<2 \mathrm{~mm}$ long. . $\ldots \ldots \ldots \ldots \ldots$.............. species nov. II

8. Calyx tube angular or lobed at anthesis. . . . . . . 9

8. Calyx tube terete at anthesis ............ 10

9. Calyx tube 10-lobed at the base ... species nov. III

9. Calyx tube 5 -angled at the base . . . . S tubulifera

10. Calyx lobes $2-5 \mathrm{~mm}$ long................

10. Calyx lobes $<2 \mathrm{~mm}$ long or rudimentary ..... 12

11. Calyx tube and lobes pilosulose ... species nov. IV

11. Calyx tube and lobes glabrous ....... S. floccosa

12. Corolla glabrous on the inside. . . . . . . . . 13

12. Corolla \pm pilose on the inside .......... 14

13. Leaf venation 3,5-plinerved; calyx lobes rudimentary ................... species nov. $V$

13. Venation pinnate; calyx lobes $>0.5 \mathrm{~mm}$ long .... ......................... S. perardua

14. Calyx lobes rudimentary........S. costaricensis

14. Calyx lobes ca. $1 \mathrm{~mm}$ long; leaves usually amplexicaule or cordate . . . . . . . . . orosiensis

\section{Synonymy:}

Symphysia costaricensis (Wilbur \& Luteyn) vander Kloet, comb. nov. $\equiv$ Vaccinium costaricense Wilbur \& Luteyn, Brittonia 29: 270. 1977.

Known from isolated collections from Heredia and San José, Costa Rica as well as adjacent Panama.
Symphysia floccosa (L.O. Williams) L.O. Williams, Phytologia 24: 158. 1972. $\equiv$ Hornemannia floccosa L.O. Williams, Brittonia 18: 248. $1966 \equiv$ Vaccinium floccosum (L.O. Williams) Wilbur and Luteyn, Brittonia 29: 272. 1977.

Endemic to the Chiriquí region of Panama.

Symphysia jefensis (Luteyn \& Wilbur) vander Kloet, comb. nov. $\equiv$ Vaccinium jefense Luteyn \& Wilbur, Brittonia, 29: 272. 1977.

Known only from a few localities in Panama.

Symphysia orosiensis (Wilbur \& Luteyn) vander Kloet, comb. nov. $\equiv$ Vaccinium orosiense Wilbur \& Luteyn, Brittonia 29: 275. 1977.

Known only from the type locality, Tapanti, Cartago, Costa Rica.

Symphysia ovata (A.C. Smith) vander Kloet, comb. nov. $\equiv$ Lateropora ovata A.C. Smith, Contrib. U.S. Natl. Herb. 28: 334. 1932.

Known only from a few collections from Cerro de la Horqueta, Chiriquí, Panama

Symphysia perardua vander Kloet, nom. nov. $\equiv$ Vaccinium santafeënse Wilbur \& Luteyn, Am. Mo. Bot. Gard. 65: 140. 1978.

This epithet is preoccupied by Lateropora santafeënsis, see below.

Known only from Cerro Tute, Veraguas, Panama.

Symphysia poasana (Donnell Smith) vander Kloet, comb. nov. $\equiv$ Vaccinium poasanum Donnell Smith, Bot. Gaz. 24: 395. 1897.

Description and distribution of this Central American endemic in Wilbur and Luteyn (1978).

Symphysia racemosa (Vahl) Stearn, Taxon 21: 111. 1972. $\equiv$ Vaccinium racemosum (Vahl) Wilbur \& Luteyn, Brittonia 29: 275. 1977.

Description, distribution and synonomy of this much described West Indian species can be found in Smith (1935), Stearn (1972) and vander Kloet (1985).

Symphysia santafeënsis (Wilbur \& Luteyn) vander Kloet, comb. nov. $\equiv$ Lateropora santafeënsis Wilbur \& Luteyn, Brittonia 29: 261. 1977.

Known only from the type collected near Santa Fé, Veraguas, Panama.

Symphysia tubulifera (Wilbur \& Luteyn) vander Kloet, comb. nov. $\equiv$ Lateropora tubulifera Wilbur \& Luteyn, Ann. Miss. Bot. Gard. 68: 162. 1981. 
Known only from the type locality, Cerro Hornito, Chiriquí, Panama.

\section{LITERATURE CITED}

Kron, K. A. \& King, J. M. 1999. Cladistic relationships of Kalmia, Leiophyllum and Loiseleuria (Phyllodoceae, Ericaceae) based on $r b c L$ and nITS data. Syst. Bot. 21: 17-29.

$\rightarrow$ Kron, K. A. \& Powell, E. A. \& Luteyn, J. L. 2002. Phylogenetic relationships within the blueberry tribe (Vaccinieae, Ericaceae) based on sequence data from matK and nuclear ribosomal ITS with comments on Satyria. Amer: J. Bot. 89: 327-336.

Luteyn, J. L. \& Wilbur, R. L. 1977. New genera and species of Ericaceae (Vaccinieae) from Costa Rica and Panama. Brittonia 29: 255-276.

Möller, M. \& Cronk, Q. C. B. 1997. Origin and relationships of Saintpaulia (Gesneriaceae) based on ribosomal DNA internal transcribed spacer (ITS) sequences. Amer: J. Bot. 84: 956-965.

Sleumer, H. 1941. Vaccinioideen-Studien. Bot. Jahrb. 7: 373-510.

Smith, A. C. 1935. Hornemannia, a much described West Indian genus. Amer. J. Bot. 2: 9-11.

Stevens, P. F. 1971. A classification of the Ericaceae: subfamilies and tribes. Bot. J. Linn. Soc. 64: 1-53.

Štorchová, H., Hrdlicková, R., Chrtek, J., Jr., Tetera, M., Fitze, D. \& Fuhrer, J. 2000. An improved method of DNA isolation from plants collected in the field and conserved in saturated $\mathrm{NaCl} / \mathrm{CTAB}$ solution. Taxon 49: 79-84.

Swofford, D. L. 2000. PAUP*. Phylogenetic Analysis Using Parsimony (*and Other Methods), version 4.0b, Computer Program. Sinauer Associates, Sunderland, Massachusetts.

Thompson J. D., Higgins, D. G \& Gibson, T. J. 1994. CLUSTAL W: Improving the sensitivity of progressive multiple sequence alignment through sequence weighting, position-specific gap penalties and weight matrix choice. Nucl. Acids Res. 22: 4673-4680.

vander Kloet, S. P. 1985. On the generic status of Symphysia. Taxon 34: 440-447.

vander Kloet, S. P. \& Patterson, I. G. 2000. RAPD assessment of novelties resulting in a new species of Vaccinium L. (Ericaceae) from Vietnam. Bot. J. Linn. Soc. 134: 575-586.

$\rightarrow$ Wilbur, R. L. \& Luteyn, J. L. 1978. Flora of Panama, part VIII, Family 149. Ericaceae. Ann. Missouri Bot. Gard. 65: 27-144. 